\begin{tabular}{l} 
RCCS \\
\hline Annual Review
\end{tabular}

RCCS Annual Review

A selection from the Portuguese journal Revista Crítica de Ciências Sociais

\#0 | 2009

Issue no. 0

\title{
Critical Edge and Legitimation in Peace Studies
}

José Manuel Pureza and Teresa Cravo

Translator: Monica Varese

\section{(2) OpenEdition}

Journals

Electronic version

URL: http://journals.openedition.org/rccsar/77

DOI: $10.4000 /$ rccsar. 77

ISSN: $1647-3175$

Publisher

Centro de Estudos Sociais da Universidade de Coimbra

\section{ELECTRONIC REFERENCE}

José Manuel Pureza and Teresa Cravo, «Critical Edge and Legitimation in Peace Studies ", RCCS Annual Review [Online], \#0 | 2009, Online since 01 September 2009, connection on 19 April 2019. URL : http://journals.openedition.org/rccsar/77 ; DOI : $10.4000 /$ rccsar.77 


\section{José Manuel Pureza}

School of Economics and Centre for Social Studies, University of Coimbra, Portugal

\section{Teresa Cravo}

School of Economics and Centre for Social Studies, University of Coimbra, Portugal

\section{Critical Edge and Legitimation in Peace Studies ${ }^{*}$}

Historically established as critical knowledge and thus an alternative to normal science in International Relations, Peace Studies came to be co-opted, in the 1990s, by the regulatory structures of the international system as a cornerstone of many of the options put into practice especially in post-war reconstruction processes. In this context, recovering the critical lineage of Peace Studies today involves two radical options. The first entails qualifying intended peace as sustainable peace. The second implies the epistemological decolonisation of Peace Studies.

Keywords: Peace Studies; International Relations; Postpositivism; Critical Theory.

\section{Introduction}

Peace Studies is invariably referred to as a salient element among the theoretical currents that embody the post-positivist rupture in the field of International Relations - in itself a heterogeneous field where feminist perspectives cross paths with critical theory studies, with deconstruction, and with new normative formulations. What unites this plurality of approaches is the challenge to the positivism of normal science in International Relations, in which retrospective validation of internal "laws" and the presumption of objective knowledge, cleansed from subjective preconceptions, are taken as axioms. In this regard, and in the context of the epistemological debate within this field of knowledge, the different postpositivist currents display the same desire to break with the realist canon of the discipline of International Relations. However, the self-representation of Peace Studies as a critical edge is currently under the closest scrutiny. Established as a discourse grounded on the aspiration to thoroughly transform reality with a view to achieving peace (at physical, structural and cultural levels), Peace Studies has become, especially since the 1990s, a conceptual and analytical field called upon to tend to public policy related primarily to the conducting of the international system by its main actors (including the major funding agencies, the platforms of global governance, and the States which control the mechanisms of international decision-making). It is thus important to examine the extent to which the alternative nature of Peace Studies has persisted in respect of the founding paradigm of this discipline.

\footnotetext{
* Article published in RCCS 71 (June 2005).
} 
We will do so in three stages. Firstly, we will follow the steps taken by this theoretical approach in its endeavour to become one of the strongest expressions of the paradigmatic alternative sought since the 1980s for a discipline (International Relations) marked at its inception by a vocation for analytical legitimation of the international order. A second stage will seek to locate the expressions of co-optation of Peace Studies - both in regard to its theoretical assumptions, and in regard to the latter's translation into public policies - and its corresponding loss of critical edge vis-à-vis the prevailing international disorder. Lastly, in the third part of our article, we will analyse the scenario of Peace Studies' theoretical and political contraction, which goes hand in hand with a resurgence of the realist paradigm appearing on the horizon at the dawn of the twenty-first century.

\section{Itinerary of a rupture foretold}

The creation of International Relations as a discipline admirably illustrates the Kuhnian relationship between paradigm, as a matricial view shared by the members of a scientific community in respect of the object of their disciplinary field, and normal science, as a certain map of knowledge espoused by such a scientific community.

To summarize the trajectory of the disciplinary formation concerned is to describe an intense paradigmatic dispute centred on rival maps of knowledge, espoused by antagonistic scientific communities. Having triumphed in the founding clash against idealism (Cravinho, 2002: 116), the realist school became the defining canon for normal science in this area. As highlighted elsewhere, realism, "segregated in the process of affirmation and consolidation of the inter-State system [...], is a specific expression of the cultural climate of scientific positivism, from which it absorbs the radical opposition between facts and values, granting absolute epistemological priority to the former over the latter" (Pureza, 2001: 9). By elevating those regularities observed in the past flow of international reality to the status of sacred laws, realism erected three standards for normal science, which constitute three defining features of the International Relations map of knowledge: State individualism, the anarchic nature of the international system, and the representation of the latter as an arena of the rawest power politics.

The simplistic nature of this map and its conservative vocation have been arraigned as challenges to the political and academic construction of an alternative paradigm. This 
challenge has only been taken seriously in the ongoing debate which pits the positivist tradition against a plurality of currents that depart, in different ways, from the epistemological and ontological premises that shape the map of normal knowledge.

As a consistent version of this alternative - based on a clear conceptual definition, a significant body of teachers and researchers and solid institutionalisation - Peace Studies has not yet been in place for fifty years. Even though its most remote origins can be found well before the $20^{\text {th }}$ century, the different proposals and initiatives designed to pursue the goal of world peace were too isolated and autonomous to be considered at the time a distinct, organised and consistent field of study (van den Dungen and Wittner, 2003: 363). The launching of the Journal of Conflict Resolution in 1957, followed two years later by the establishment of the Center for Research on Conflict Resolution at the University of Michigan, by Kenneth Boulding and his colleagues Herbert Herman and Anatol Rapoport, represented the first challenge to the realist paradigm as the predominant model for interpreting the phenomena of peace and war. However, the search for scientific recognition of a discipline then still in its infancy - precisely at a time when positivism in the social sciences had reached its zenith - confined the behaviourist-inclined U.S. school to quantitative and non-valuational data gathering on conflicts (Terrif et al., 1999: 69). Research was thus restricted in its concept of peace - presented in its negative formulation as an absence of war and violence - and consequently in its agenda - markedly minimalist, as it sought only to reduce the occurrence and the spreading of conflicts.

Until then, as Martinez Guzmán states, the main challenge for this new research approach was precisely that of turning peace itself into an object of analysis (2005: 49). The figure who sparked this turning point - and who is, for this very reason, regarded as the founder of Peace Studies - was the Norwegian Johan Galtung. The new direction of this field of studies - begun with the creation of the Oslo Peace Research Institute in 1959, and five years later, the Journal of Peace Research - is unequivocally rooted in this author's original proposal.

In characterising Peace Studies, Galtung drastically shattered the positivistic distinction between theory and practice. Surpassing the false notion of the neutrality of science (since it was acknowledged that all types of knowledge inevitably presuppose a value-laden gaze on the part of analysts), Peace Studies asserted itself as a "socially productive" discipline - that is, one that produces effects on the social, political, economic and cultural life of societies. 
These effects are intended to be consistent with the goals of promotion of cooperation, peaceful resolution of disputes and non-violent social and political change. In other words, Galtung embodied the resurgence of normative theory - the major novelty of this social science - by affirming a commitment to values, especially a commitment to peace. According to McSweeney (1998), without this central normative claim, Peace Studies would surely have lost "its raison d'etre as a distinctive approach to the international order." To know about the values of peace is thus not sufficient: an "emotional adherence to these values" is most particularly demanded (Martinez Guzman, 2004:412). Within the framework of an intimate link between theory and practice, theoretical production is "prospective and prescriptive" (Pureza, 2001: 14): it is only complete when it actively fosters the commitment to peace and takes shape in concrete strategies. Faced with the critiques of those who greeted with scepticism his goal of studying peace scientifically by means of a normative theory, Galtung responded by using his famous medical analogy: Peace Studies, ethically directed towards peace (as opposed to violence and war), would be no less rigorous than medical research, ethically directed towards healing (as opposed to illness) (Galtung, 1996: 1).

Additionally, emphasis should be given to the fact that, in this school of thought, searching for non-violent processes of political change necessarily implies profound transformations in existing power structures (Rogers and Ramsbotham, 1997: 753). In other words, by taking Peace Studies as a simultaneously analytical and normative instrument, the international system does not remain unscathed vis-à-vis the intent to change an unjust status quo that fosters inequalities. Galtung thus built up a distinction in the conceptualising of peace which was to become key to the development of this discipline - "negative peace," as an absence of war, and "positive peace," as integrated human community, as social justice and freedom.

Furthermore, in Galtung's view Peace Studies should be interdisciplinary, inasmuch as dialogue between International Relations and the different approaches of the social sciences, such as sociology, anthropology or psychology, can contribute to the decisive enriching of the conceptual framework for interpreting both peace and violent conflicts, given their multifaceted nature (Rogers and Ramsbotham, 1999: 741).

This alternative focus of analysis in Peace Studies, as it was developed in Northern Europe, would become pivotal for further developments in this area of studies. It became the basis of a different orientation from that of its North-American counterpart, and thus 
provided a response to critiques which in the meantime had been levelled at this field. Underlying these critiques were charges regarding the persistence of epistemological traces of realism in the theoretical frameworks of peace research, which thus could not break free from the accusation of legitimising the world system's power relations (Terrif et al., 1999: 70-71).

The recognition of both the reproduction of the hierarchy between centre and periphery, ${ }^{1}$ and its legitimisation by means of the prevailing paradigm in International Relations, as well as the fact that Peace Studies was not fully equipped to challenge either situation, gave rise to a major reconceptualisation of the discipline, set in motion by Galtung's creative impulse.

The Nordic author identified the triangle of violence, in apposition to which he set the triangle of peace. The distinction between the three vertices is made in accordance with different time frames:

Direct violence is an event; structural violence is a process with ups and downs; cultural violence is an invariant, a 'permanence' [...] The three forms of violence enter time differently, somewhat like the difference in earthquake theory between the earthquake as an event, the movement of the tectonic plates as a process, and the fault line as a more permanent condition. (Galtung, 1990: 294)

Direct violence is thus posited as an intentional act of aggression; structural (indirect) violence derives from the social structure itself - repression, in its political form, or exploitation, in its economic form; and lastly, cultural violence underlies structural and direct violence, making up the system of norms and behaviours which bestows social legitimacy on the preceding types (Galtung, 1996: 2).

Peace Studies has traditionally focused on direct violence (obvious and sudden) - which, on being eliminated, represents negative peace - rather than on structural and cultural violence (static and concealed) - which, on being eliminated, creates positive peace. In the broadest sense of the term, peace - i.e., direct peace + structural peace + cultural peace ultimately corresponds to Galtung's ambition, given that the mere absence of war can hide deeper instances of injustice which, if not addressed, may contain the seeds of potential, violent conflicts (Terriff et al., 1999: 193).

\footnotetext{
${ }^{1}$ As Boaventura de Sousa Santos reminds us $(2004: 8,19)$, colonialism as a socio-economic relation survived colonialism as a political relation, retaining, in virtually unaltered form, the structural patterns of oppression, discrimination and violence.
} 
With this trilogy, Galtung laid bare the global dynamics of exploitation, responding to the critique that traditional Peace Studies colluded with the dominant conception of power, and broadening the spectrum of his action-research, previously centred on the strategic relation between the superpowers and on the logic of dissuasion. In addition, the unit of analysis broadened to encompass not only the nation-State, but also the dynamics of class and power at the intrastate and transnational levels. This was a significant change with respect to the prevailing paradigm after World War II (ibid.: 193).

Materialising this normative shift within Peace Studies, the agenda structured throughout the 1980 s - articulated with a solid academic-institutional base - gave clear priority to topics such as disarmament, the transformation of the unequal global system, environmental issues and the analysis of processes of conflict negotiation and mediation (Miall, Ramsbotham and Woodhouse, 1999: 48-49). In following the key issue of that decade's international politics - disarmament (as a counterpoint to the superpowers' arms race and the beginning of the "Second Cold War") - Peace Studies displayed an unprecedented capacity for theoretical production. But the great prominence that this area achieved at the time was mainly due to its appropriation by pro-peace and anti-nuclear social movements. Campaigns for peace and the pro-nuclear-disarmament movement, which grew and diversified, illustrate the capacity of Peace Studies to include in its agenda topics which were traditionally marginalised by the mainstream (Van den Dungen and Wittner, 2003: 365). Likewise, they reflect the action-research dialectic so dear to this discipline, spotlighting its affinity with activism. By the end of the 1980s, the Peace Studies community had become a diverse, active school, with effective international impact (Rogers and Ramsbotham, 1999: 749).

\section{Emancipation or standardisation?}

The end of the Cold War was a turning point in the assertion of the field of Peace Studies. Countering fears of its loss of relevance in a world lacking bipolar confrontation, the 1990s offered a unique opportunity for Peace Studies to contribute directly to the resolution of the growing number of particularly long and violent civil conflicts which challenged the stability of the new world order.

These "new wars" (Kaldor, 1999) demanded the commitment of the international community and prompted the emergence of a model of response that would take into 
account the sources, the actors, the dynamics, as well as the consequences of the new patterns of conflict - already discernible since World War II, but which the end of the bipolar system had clearly intensified (Rasmussen, 1999: 43). In this context, the doctrinal and institutional stance taken by the United Nations in the early 1990s proved to be structuring. Realising that there was an opportunity for expanding the UN role, and embracing the widespread expectations for a rebirth of the organisation at the end of the bipolar confrontation (Roberts, 1998: 300), the Secretary General, Boutros-Ghali, proposed that the UN's work (and that of the international community in general) should be centred on the proliferation of internal conflicts within endemically fragile States positioned on the peripheries of the world system. This meant involving the organisation in actively fostering the peaceful resolution of these conflicts, by closely following negotiations on political agreements and by committing itself to assist in the implementation of peace processes ensuing from these agreements.

The need to set up a framework for action to respond to this challenge cleared the way for assimilating and subsequently applying the theoretical assumptions that had been put forward by Peace Studies. The first close contact of this discipline with the UN came precisely with the Agenda for Peace in 1992 (Boutros-Ghali, 1992: 11), whose strategies for action - preventive diplomacy, peacemaking, peacekeeping and peacebuilding - stemmed from concepts formulated by Galtung in the 1970s. The comprehensive application of these strategies virtually all over the world during the 1990s, made it possible for Peace Studies to be included in the so-called policy-oriented mainstream. Starting out as theoretical assumptions, they became real social norms, accepted and reproduced by the community (Santos, 1978). This was a sign that the field of Peace Studies was entering into a period of "scientific normalisation," which entailed, to return to Kuhn, defending, broadening and deepening the paradigm, by resolving problems in accordance with the new, assimilated modes of solution.

This discipline thus benefitted from the new world order, and took on a major role in the international decision-making system, a role it had not until then played. Beginning with the UN, its hegemony was welcomed by the scientific community, by multilateral organisations, by donor countries, and by NGOs, and was appropriated by these actors as a guide for devising peace-promoting policies. 
Faced with the intensifying of post-Cold War internal conflicts in the so-called failed States within the contemporary world system (Ayoob, 1996: 67) - States whose attempt at centralising the power inherent to State-building had failed - the policies grounded in Peace Studies took on a standardised pattern. This standardisation implied the transformation of situations of near anarchy into situations of centralised, legitimate power, with actual capacity to deal with the problem of security and with the political, economic and social inadequacies experienced by the countries concerned. In other words, the response of the international community would include, in practical terms, support to post-war (re)construction of the State itself (peacebuilding).

As the expression of a dominant scientific model in this area, post-war reconstruction conveys a certain methodological conception, proposing standardised rules and technical procedures to resolve the problems faced by States riven by internal strife. The model inevitably splits into four dimensions - military and security, political-constitutional, economic-social, and psychosocial - regardless of the context to which it is applied, giving shape to what Oliver Ramsbotham (2000) calls standard operating procedure.

The most often voiced criticism of this model has to do with the standardised nature of the framework for action. Since it is a single, generically applied model, it fails in not allowing much room for neither local singularities nor the emergence of alternative solutions that might be more appropriate for the different realities. This criticism of standardisation is all the more incisive as we find that this model, aspiring to universal application, does not comprise multicultural experiences. Rather, it confines itself to reproducing a clear Western matrix in countries that are overwhelmingly non-Western. Thus, this approach gave rise to a number of criticisms, ranging from the culturally insensitive behaviour displayed by troops on the ground, to the rejection of the so-called model of liberal internationalism (Paris, 1997), based on two pillars in particular: electoral democracy and the market economy.

The triumphant emergence of this liberal recipe after the end of the Cold War and the collapse of the Communist Bloc led to ample endorsement of this kind of approach. Being unchallenged, it was even forced upon the four corners of the earth (Clapham, 1998: 193-194). Hence, it is understandable that local agents should have a reduced role in determining the agenda for the reconstruction of their own countries. There has been an unequivocal failure in amply exploring the virtues of local capabilities, insofar as the model further endorses excessive centralisation of decision-making in the United Nations itself and 
in small elites with prior connections to the conflict. In fact, there has been a chronic lack of attention to what might be called the base of the pyramid, which corresponds to the majority of the population. The idea of consolidating peace from below has been thwarted by the top-down, State-centred approach adopted by the United Nations, which neglects indigenous resources and agents that are crucial in building a more participatory democracy and a more inclusive and, necessarily, more sustainable peace.

Feminist critiques (by authors such as Betty Reardon and Birgit Brock-Utne) have been particularly scathing in denouncing the fact that this peacebuilding model actually reproduces the relationship between dominator and dominated. In questioning the stereotypes that give rise to these practices, such as women's inherent passivity in both war and peace, feminist critiques contest the secondary, virtually invisible or even non-existent role of women, systematically relegated to the informal sphere and to the psychosocial dimension of peacebuilding. Their contributions have been most useful in condemning the public discrimination to which women are subjected - with some noteworthy exceptions - in the negotiation, signing and implementation of peace agreements, resulting in their considerably limited access to the decision-making process in post-conflict situations (Moura, 2005).

These critiques show that the knowledge produced is concentrated in the mechanisms that reinforce domination and instruments of control. By pre-determining an institutional framework as if it could automatically achieve the supposedly unquestionable goals of peacemaking, Peace Studies showed that it was not open to incorporate and put into practice the new creative, critical and constructive inputs from perspectives such as development theories and practices, critical social theory, cultural and gender analysis, among others.

The experience of the 1990s thus seemed to represent the climax of the discipline's institutionalisation: Peace Studies provided the hegemonic models, and dominant institutions imposed them. As highlighted in the collective work Security Studies Today, referring to the post-World War II period, "'Peace' fell within the domain of high politics, imposed on States by supranational institutions as a product of a hierarchical power relationship, and consonant with an external, categorical notion of a notion of 'the good' for international actors" (Terrif et al., 1999: 68). 
The new circumstances might have led to the development of quite ambitious actionresearch as a distinctive feature of Peace Studies, insofar as much of its theoretical production was applied to public policies for the promotion of peace. However, the 1990s worked as a test of the veracity of the post-positivist formulation which this area of study had explored and somehow abandoned. Peace research was put at the service of a lyophilised universalisation of institutional and political models produced by Western modernity, proving it had not yet succeeded in breaking free from this domain (Santos, 2004: 16). In this sense, the experience of the post-Cold War period showed the extent to which Peace Studies fell short of what was needed to carry out the paradigmatic transition in epistemological terms, and above all in social and political terms.

\section{Paths and detours in a return to critique}

As an institution, Peace Studies appears nowadays to have lost some of its rhetorical appeal (Patomaki, 2001: 734). The end of the Cold War, its association with neoliberalism conveyed by post-war reconstruction models imposed throughout the 1990s, and the distancing from its original conceptual formulation, made in the 1970s, may have prompted the decline in the discipline. Having emerged as a form of critical knowledge - committed to putting in place a normative, emancipatory project - Peace Studies proved in the end to be easily co-opted into the hegemonic discursive and ideological bloc.

By disfiguring the project that motivated the founding fathers to break drastically with the positivist-realist tradition of International Relations, Peace Studies has been unable to present itself as an alternative to the outlook and discourse legitimising the practices of domination concealed within the prevailing paradigm. What's more, it runs the risk of becoming a locus for the legitimising and refining of the established power system. It is surely no accident that the main research centres in this field have shifted from developing primarily theoretical work to increasingly providing consultancy services in the context of international operations "on the ground."

The radical nature of the alternative that it set out to be tends to remain within the confines of the conceptual plane, without materialising in the design and implementation of policies. The risk of instrumentalisation is thus great, facilitated to the extent that Peace Studies explicitly defines itself as a policy-oriented field of action-research. What is in fact at 
stake is not leaving behind "theoretical purity," but rather the loss of critical capacity vis-à-vis the emerging systems of international domination. In these circumstances, the intimate link between academic theory and community practice may prove to be counterproductive, as it reinforces the structural, relational and cultural contradictions that lead to conflicts.

In our view, Peace Studies now are, to some extent, confronted with a challenge identical in nature to that which was in place during the reflection on economic development processes from the 1980 s onwards. In the same way that it became increasingly obvious that proceeding with development policies that were deliberately blind to the depletion of natural resources would result in eventual catastrophe, thus too it has now become clear that the aim of building a solid peace calls for a critical distancing from all sources of violence, even (and especially) when these appear in the guise of instruments that normalise or reduce merely epidermic violence. However, the challenge does not end here. There are lessons to be learnt from the way the demand for sustainability was assimilated by development policies. What was originally supposed to be a basis for radically distinct policies has become, with the concept of sustainable development - or at least with the dominant practices associated with it - a means of saving business-as-usual, lending it a slightly greener shade.

It is our understanding that the challenge of a sustainable peace cannot mean less than an unequivocal distancing from institutional prescriptions, from the power relations and social relations which neoliberalism carries within it. Very tangibly put, this means that setting sustainable peace as a goal of peacebuilding processes implies not only eradicating war and its immediate aftermath, but also creating conditions to prevent military violence from being replaced, in the short or long run, by steadily intensifying social violence. This type of violence is seen in exponentially rising indices of domestic violence and crime, or in the reconfiguration of relations between political forces, as well as between these and the population at large, in ways that truly clone the relations that created the conditions for and perpetuated war. These are perhaps the two most perverse results of a mechanical application of the standard operating procedure, and of the central role that it gives to the articulation between neoliberal, low-intensity democracy and structural economic adjustment. 
In this context, Peace Studies are in want of a profound decolonising process. What has until now been a solid conceptual formulation coming from the North, more than ever needs incorporate contributions from the South and its singularities. If Peace Studies does this, it will be able to re-invent its emancipatory character and rid itself of the social and political praxis to which it has hitherto subscribed (Santos, 2004: 6). A first step in this direction is to acknowledge that war is a structural social condition of the periphery, and this necessarily entails opening up this field of studies to formulae and experiences of peace that are rooted in the selfsame territories of violence and conflict. The institutional framework which is most appropriate for the goal of sustainable peace must be supplied by the context in each case, seeking to meet real local needs and aspirations. In very concrete terms, learning from the South means that public policies underpinned by Peace Studies' conceptual universe, notably in post-conflict reconstruction or conflict prevention and crisis management, must achieve greater distance from the standardised prescriptions formulated in the universities and chancelleries of the North; policies need to confer a more central role on local actors, be it by paying greater heed to practices rooted in local customs and to regional cultural and social contexts, or by giving absolute priority to the empowerment of local societies.

However, this need to critically re-centre Peace Studies is at present faced with an adverse climate. In the post-9/11 international system, the realist paradigm has resurfaced, claiming to have a more accurate worldview of the dawn of the $21^{\text {st }}$ century. The emergence of the "war on terror," as a guiding principle for the response to the new threats to worldwide security and stability, has imposed a dramatic narrowing of the international agenda, which Peace Studies has neither been able to prevent nor, so far, to reverse.

Similarly to what happened in the ten years following World War II, when the realist paradigm ruled unchallenged over the analysis of international relations, so now Peace Studies have allowed themselves to be taken hostage by the idea of the inevitability of conflict. Considering the 9/11 attacks in isolation and analysing them simplistically, without questioning their relations to the disorder or the power relations of the current international system, have silenced that which ought to be the contribution of this discipline. In this context, Peace Studies runs the risk of becoming marginalised and relegated to certain "agenda niches" - such as post-war reconstruction, environmental issues, or nuclear disarmament - thus being cut off from its true emancipatory vocation. 
Disarmament will, no doubt, continue to be a pressing issue on the agenda of Peace Studies, especially in this new post-Cold War nuclear era. The risks of nuclear weapon use which, since 1945, has posed a prevailing threat to worldwide stability - remain, now within a scenario of insecurity marked by horizontal proliferation and by the tension between the desire of new States to gain entry into the nuclear club and their repression by those who already possess such capabilities. However, Peace Studies are now far from being able to mobilise the pro-peace and anti-nuclear movements in numbers equalling those of the last years of the Cold War, whose activism contributed in such large measure to foreground the cause as well as the discipline itself.

There remains yet another scenario, which, if it becomes a reality, may especially penalise Peace Studies: that of the "originality" of the realist paradigm in its second life-stage launched after $9 / 11$. The re-emergence of this paradigm in and of itself appears as déjà vu in the emphasis it gives to military readiness, in its discourse on the inevitability of clashes between States or in its pursuit of the national interest. Yet, it also displays particularities that have nothing to do with the assumptions we have grown accustomed to associating with this traditional view of International Relations. As the war against Iraq shows, we are dealing today with a realism dressed up as democratic missionising - one that appropriates the normative discourse which had been traditionally alien to it and invokes the commitment to certain values in order to legitimise the war. The very same quarters that defended "anarchy" now lay claim to the image of "community." Using the same bases of the critique of violence, but at the service of the moral legitimising of war, they are progressively taking over the ethical and normative field of Peace Studies.

\section{Conclusion}

The transforming promise conveyed by Peace Studies lost its character in the standardising of peacebuilding policies in the 1990s, and today stumbles against the polymorphous resurgence of realism as a discourse that is allegedly more appropriate to the circumstances of the international relations system. The political contraction of Peace Studies, which consigns it to a status of instrumental utility in the management of the peripheries of the world system, also entails a theoretical contraction. However, the genetic particularity of Peace Studies resides precisely in its radical nature. It is this radical nature that will bring to a 
halt its slide to the locus of normal science - a science closed to innovation, that canonises the future in terms of the past.

For this reason, and in order to achieve its full post-positivist expression, Peace Studies must now radicalise its critical approach, assuming the biases and flaws of the concepts underlying Western modernity and, as a result, opening up to heterogeneity, to plurality, to the periphery and to the epistemological contributions of feminist, environmental and cultural studies. Decolonising its knowledge and striving for sustainable peace appear as the necessary tools for the return of Peace Studies to its critical vocation. Only thus will Peace Studies become a vehicle for overcoming relations of power and domination, whose indictment and deconstruction determined its birth and affirmation. It is only thus that its emancipatory goal of social transformation will materialise and that its conversion into a new form of social oppression can be averted.

Translated by Monica Varese

Revised by Teresa Tavares

\section{References}

Ayoob, Mohammed (1996), "State-Making, State-Breaking and State Failure: Explaining the Roots of 'Third World' Insecurity," in Luc van de Goor et al. (eds.), Between Development and Destruction. An Enquiry into the Causes of Conflict in Post-Colonial States. London: MacMillan, 67-90.

Boutros-Ghali, Boutros (1992), An Agenda for Peace. New York: United Nations.

Clapham, Christopher (1998), "Rwanda: The Perils of Peacemaking," Journal of Peace Research, 35(2), 193-210.

Cravinho, João (2002), Visões do mundo: as relações internacionais e o mundo contemporâneo. Lisbon: Imprensa de Ciências Sociais.

Dungen, Peter van den; Wittner, Lawrence (2003), "Peace History: An Introduction," Journal of Peace Research, 40(4), 363-375.

Galtung, Johan (1990), “Cultural Violence," Journal of Peace Research, 27(3), 291-305.

Galtung, Johan (1996), Peace by Peaceful Means: Peace and Conflict, Development and Civilization. London: Sage.

Kaldor, Mary (1999), New and Old Wars. Cambridge: Polity Press.

Martínez Guzmán, Vincent (2004), "Epistemologías para la Paz," Enciclopedia de Paz y Conflictos. Granada: Editorial Universidad de Granada.

Martínez Guzmán, Vicent (2005), Podemos hacer las paces. Reflexiones éticas tras el 11-S y el 11-M. Bilbao: Desclée De Brouwer, S.A. 
McSweeney, Hill (1998), "Peace Studies \& IR Theory after the Cold War," Peace Studies Section Newsletter (Syracuse University). Available at http://www2.mcdaniel.edu/ peacestudies/pdf/newsletters/nov98.pdf

Miall, Hugh; Ramsbotham, Oliver; Woodhouse, Tom (1999), Contemporary Conflict Resolution. Cambridge: Polity Press.

Moura, Tatiana (2005), Entre Atenas e Esparta. Mulheres, paz e conflitos armados. Coimbra: Quarteto.

Paris, Roland (1997), "Peacebuilding and the Limits of Liberal Internationalism," International Security, 22(2), 54-89.

Patomaki, Heikki (2001), "The Challenge of Critical Theories: Peace Research at the Start of the New Century," Journal of Peace Research, 38(6), 723-737.

Pureza, José Manuel (2001), "Estudos sobre a paz e cultura da paz," in J. M. Pureza (ed.), Para uma cultura da paz. Coimbra: Quarteto Editora

Ramsbotham, Oliver (2000), "Reflections on UN Post-Settlement Peacebuilding," in Tom Woodhouse; O. Ramsbotham (eds.), Peacekeeping and Conflict Resolution. London: Frank Cass Publishers, 169-189.

Rasmussen, J. Lewis (1999), "Peacemaking in the Twenty-first Century," in William Zartman; J. L. Rasmussen (eds.), Peacemaking in International Conflict - Methods and Techniques. Washington, D.C.: United States Institute of Peace Press, 23-50.

Roberts, Adam (1998), "The Crisis in UN Peacekeeping," in Chester A. Crocker et al. (eds.), Managing Global Chaos - Sources of and Responses to International Conflict. Washington, D.C.: United States Institute of Peace Press, 297-319.

Rogers, Paul; Ramsbotham, Oliver (1999), "Then and Now: Peace Research - Past and Future," Political Studies, 47(4), 740-754.

Sousa Santos, Boaventura (1978), "Da sociologib a da ciência à política científica," Revista Crítica de Ciências Sociais, 1, 11-56.

Sousa Santos, Boaventura (2004), "Do pós-moderno ao pós-colonial. E para além de um e de outro," Keynote Address, 8th Luso-Afro-Brazilian Congress of the Social Sciences, 16-18 September. Available at http://www.ces.fe.uc.pt/misc/Do pos-moderno ao poscolonial.pdf.

Terriff, Terry et al. (1999), Security Studies Today. Cambridge: Polity Press. 